Egyptian J. of Nutrition Vol. XXXVI No. 2 (2021)

\title{
Relationship between Nutritional Status and Cognitive Performance among Primary School Students
}

\section{Rania A.Bassuoni', Laila Hussein', Magda S.Mohamed', Zeinab M.Monir ${ }^{2}$ and Ashraf A.AbdEI-Megeid ${ }^{3}$}

1Departments of Nutrition and Food Science, National Research Center, Giza, Egypt

2Departments of Child Health National Research Center, Giza, Egypt 3Department of Nutrition and Food Science, Faculty of Home Economics, Helwan University, Cairo, Egypt

\begin{abstract}
A satisfactory diet is necessary for normal brain progress. Healthily nutrition is important especially at critical growth stages. Throughout childhood, under-nutrition causes children to have poor energy, which has adverse effects on cognitive development and academic performance. Under-nutrition also affects physical growth and maturation, therefore affecting growth rate, body weight, and final height. The present study is aimed to assess the nutritional status and cognitive performances in some school- age children (72119 months). The present study is done on 51 students 25 boys and 26 girls with a mean age of $95.75 \pm 1.77$ months. All students from cities Giza government. The mean average body weight, body height, $\mathrm{BMI}$, and MUA were 23.65 $\pm 0.44 \mathrm{~kg}, 122.79 \pm 0.9 \mathrm{~cm}$,




\title{
Rania A.Bassuoni - Laila Hussein - Magda S.Mohamed Zeinab M.Monir and Ashraf A.AbdEl-Megeid
}

\begin{abstract}
$15.62 \pm 0.14 \mathrm{~kg} / \mathrm{m}^{2}$, and $18.63 \pm 0.33 \mathrm{~cm}$ respectively. The mean average intake of total energy, protein, fat, and carbohydrate was $1185.02 \pm 29.12 \mathrm{kcal}, 39.19 \pm 0.99 \mathrm{~g}, 39.40 \pm 1.27 \mathrm{~g}$, and $141.88 \pm 3.47 \mathrm{~g}$ respectively. The mean average intake of some minerals (lodine, Iron, Selenium, and Zinc) was $83.08 \pm 5.47 \mu \mathrm{g}, 10.45 \pm 0.56 \mathrm{mg}$, and $49.32 \pm 2.05 \mu \mathrm{g}$ and $4.75 \pm 0.19 \mathrm{mg}$ respectively. The mean average intake of some vitamins (Vitamin A, Vitamin B1, Vitamin B2, and Vitamin C) was $293.83 \pm 23.24$ R.E, $0.41 \pm 0.04 \mathrm{mg}, 0.47 \pm 0.03 \mathrm{mg}$, and $16.51 \pm 0.97 \mathrm{mg}$ respectively. Some biochemical analyses were done, the mean average urinary iodine was $155.29 \pm 3.53 \mu \mathrm{g} / \mathrm{l}$, and blood hemoglobin was $11.49 \pm 0.07 \mathrm{~g} / \mathrm{dl}$. The Wechsler tests were done to calculate student intelligence quotient (IQ), the mean average of verbal IQ was $98.43 \pm 0.99$, the mean average of performance IQ was $95.09 \pm 0.42$, and the mean average of total IQ was $96.69 \pm 0.42$.From these results, it could be concluded that nutritional status may affect cognitive development, and the interventions and dietary supplements may improve cognitive abilities in children.
\end{abstract}

\section{Introduction}

Nutrition is one of many factors that influence brain progress, consequently, the development of children cognitive. These factors fall into two broad categories, genetic and environmental. Nutrition is a part of the biological environment that affects the brain and cognitive development (Bryan et al., 2004). 
Egyptian J. of Nutrition Vol. XXXVI No. 2 (2021)

Investigating nutrition role cognitive development is expected to be challenging, because nutrition is likely to be an outcome of or link with internal and external environmental factors for instance demographic, socioeconomic, health, social, behavioral, and motivational influences, and also may interact with genetic influences, making its effects not easy to specify (Wachs, 2000).

Not only is the timing of nutritional influences complex, but also the nature of nutritional influences on cognitive development is involved. The intake of macro- and micronutrients may have interactive effects on the brain and cognitive development.

School-age is the active growing period of childhood (Bryan et al., 2004).

Primary school age is a dynamic time of physical growth in addition to child mental development (Srivastava et al., 2012).It is well recognized that suffering from under or over-nutrition during the school years can inhibit a child's physical and cognitive development. Stunting (low height-for-age) is linked to long-term consequences, such as impaired intellectual achievement and school performance, and also leads to decaling adult body size and, subsequently, reduced work ability and obstetric complications (Martorell et al., 1992). Growth monitoring is globally used to assess nutritional status, children's health, and development. Anthropometric assessment is an almost fixed tool to assess health, and nutritional conditions in childhood (Kuczmarski et al., 2002). 


\title{
Rania A.Bassuoni - Laila Hussein - Magda S.Mohamed Zeinab M.Monir and Ashraf A.AbdEl-Megeid
}

\begin{abstract}
Research indicates that health problems due to poor nutritional status in primary school-age children are the most common causes of low school attendance, high absence, early failure, and poor classroom performance (Best et al., 2010).
\end{abstract}

Adequate micronutrient status is vital for good health and development during childhood. Anemia, which can result from iron, folate, or vitamin B12 deficiency, among other causes, negatively impacts work capacity, intellectual performance, and child cognitive development (de Benoist et al., 2008). Vitamin A plays a serious role in eye health and immune function and also plays a role in the etiology of anemia (Sommer and Davidson, 2002). Sufficient iodine is crucial to the growing child to optimize mental development and prevent goiter and its complications (Allen et al., 2006), while zinc is necessary for many biologic processes and it's deficiency can affect brain development and cognition (Golub et al., 1995).

There is increasing evidence that improving the nutrition of schoolchildren can have a measurable positive impact on cognition, linear growth, and other health outcomes. Access to high-quality data on nutrition and health indicators in this age group would aid in prioritizing and setting up deliberate, evidence-based nutrition intervention programs, targeting the nutritional problems that are of real concern (Whaley et al., 2003). Many governments, multilateral and bilateral organizations, and other actors recognize that good health and nutrition of children during the primary-school years 
Egyptian J. of Nutrition Vol. XXXVI No. 2 (2021)

contribute to educational achievement, growth, and development. Schools are a practical platform to deliver an integrated package of interventions, such as nutritious meals or snacks, micronutrient supplements or on-site fortification, infection control, health promotion, and life-skills education, to improve the health and nutrition of schoolchildren (Best et al., 2010).

There for the objectives of the present study are to assess the nutritional status and cognitive performances of some school-age children (72-119 months).

\section{Subject and Methods}

Study Design: Fifty-one healthy children of both sexes aging 72-119 months were recruited from the urban area of Giza governorate. They were attending Primary schools during the academic year 2019-2020. The personal data were collected by their mothers and their ages were assessed from the birth certificates they were excluded if a physical or mental disability was present or ill children at the time of the study.

\section{Data Collection and Field Work}

Data collection took place through a home visit. An informed consent form was signed by the parent before participation in the study. The study was approved by the ethical committee of the National research center with registration numbers 18-105. Anthropometric measurements were conducted on the children while 


\section{Rania A.Bassuoni - Laila Hussein - Magda S.Mohamed Zeinab M.Monir and Ashraf A.AbdEl-Megeid}

the parents were being interviewed and a questionnaire was filled by the investigator on some personal data, socio-demographic background, and 24-hour recall of their children. Subsequently, a cognitive assessment was conducted on the students one-to-one.

\section{Anthropometric measurements}

1- Age was assessed from birth certificates.

2- Body weight was assessed using a beam-type balance while the child wore very light clothes and was barefooted. This weight was taken to the nearest $0.5 \mathrm{~kg}$ (Jelliffe et al., 1989) using a kilogram weighing balances ranging from 1-130 kilograms.

3- Body height was measured to the nearest $1 \mathrm{~mm}$ for children. Height measurements were taken, while the subject was standing position against a firm wall with a fixed scale. Height was taken with no shoes and recorded to the nearest centimeter (Moussa, 1999).

4- Mid-upper arm circumference (MUAC): was measured to the nearest $0.1 \mathrm{~cm}$ with non-elastic tape over light clothing on the upper left arm. The children stood relaxed to the trained technician and the arm hanging freely at the side; the tape was passed around the arm at the level of the mid-point of the upper arm (Mazicioglu et al., 2010).

\section{Dietary intake}

Triple 24-hour dietary recalls were administered to the children's mothers Dietary data were translated into nutrient intake data using a specifically designed nutrient database, (The Egyptian 
Egyptian J. of Nutrition Vol. XXXVI No. 2 (2021)

Food Composition Tables and Nutrient Data Base Management System from National Nutation Institute, 2006).

\section{Cognitive Tests}

Cognitive and intellectual functioning was assessed through the application of the Wechsler Intelligence Scale for Children (WISC$\mathrm{R}$ ), the Arabic version (Ismaiel and Kamal, 1999).

It is designed to assess and measure the child's verbal, performance, and full-scale IQ through assessment of different functions (shortand long-term memory, comprehension, information, abstract thinking, problem-solving, and speed of information processing), thorough application of (WISC-R), we can assess verbal and practical intelligence quotient (IQ) as well as total IQ (Kaufman et al. 2016).

\section{Biochemical analysis:}

1- Blood Hemoglobin: Hemoglobin estimation was done according to Shaklai et al., (1977). In a reagent solution, the ferrous ions of hemoglobin are oxidized to the ferric state by potassium ferricyanide to form methemoglobin. Methemoglobin subsequently reacts with the cyanide ions provided by potassium cyanide to form cyanmethemoglobin.

Hemoglobin + Cyanide+Ferricyanide $=$ Cyamethemoglobin(Ion) . The amount of cyanmethemoglobin can be measured spectrophotometrically at a wavelength of wavelength $546 \mathrm{~nm}$. The intensity of the color is directly proportional to hemoglobin concentration in the specimen.

2- Urinary lodine: Urinary lodine was determined according to (WHO, 2013). Urine samples were thawed and mixed thoroughly on a rot 


\section{Rania A.Bassuoni - Laila Hussein - Magda S.Mohamed Zeinab M.Monir and Ashraf A.AbdEl-Megeid}

mixer before pipe ting. $250 \mu \mathrm{l}$ of urine were taken into $13 \mathrm{X} 100 \mathrm{~mm}$ scrolled test tubes then adding $1 \mathrm{ml}$ of $\mathrm{M}$ ammonium per sulfate to each tube and the samples were hydrolyzed for $1 \mathrm{~h}$ at $100^{\circ} \mathrm{C}$. After cool the tubes to room temperature add $2.5 \mathrm{ml}$ arsenious acid solution and mix well then incubate for 15 minutes. Add $300 \mu$ of ceric ammonium sulfate to each tube, and then incubate for 30 minutes. Readings were performed using a spectrophotometer (Thermo Fisher Scientific Genesys, USA) at $420 \mathrm{~nm}$, within 30 minutes.

Statistical Analysis Data were analyzed using SPSS Version 20.0 for Windows (Statistical Package for the Social Sciences)

\section{Results and Dissection}

Table (1) illustrates the Characteristics of children who participate in the study, the number of children in the study was 51 with a mean average age of $95.73 \pm 1.77$ months, 25 boys (98.38 \pm 2.39 month) and 26 girls (95.73 \pm 1.77 months). All children live in the cities of Giza Governorate. When asking children mothers some questions about the method of delivery, birth weight, as well as breastfeeding it was found that only $33.33 \%$ of children were born in a normal way not cesarean, the mean average of their birth weight was $3.43 \pm 0.06 \mathrm{~kg}$ and $47.06 \%$ of them were breast fed, also when asked children mothers about the time of their children watch T.V, Mobile and Computer we found that they watched them for $4.37 \pm 0.18$ hour/ day, and only $50.98 \%$ of children were playing sports. The 
Egyptian J. of Nutrition Vol. XXXVI No. 2 (2021)

weights of children were $23.65 \pm 0.44 \mathrm{~kg}$, heights were $122.79 \pm 0.90$ $\mathrm{cm}$ so BMl was $15.62 \pm 0.14 \mathrm{~kg} / \mathrm{m}^{2}$, and MUA were $18.63 \pm 0.33 \mathrm{~cm}$.

Trend analysis of 2005-14 EDHS data revealed that deliveries by CS have more than doubled between 2005 and 2014 such that 19.9 percent of all live births occurring in the five years preceding the 2005 EDHS were via CS compared to 51.8 percent in 2014 (Abdel-Tawab et al., 2018). Polidano et al, (2017) demonstrated that across several measures, we find that cesareanborn children perform significantly below vaginally-born children, by up to a tenth of a standard deviation in national numeracy test scores at age 8-9. Estimates from a low-risk sub-sample and lower-bound analysis suggest that the relationship is not spuriously related to unobserved confounding. Lower rates of breastfeeding and adverse child and maternal health outcomes that are associated with cesarean birth are found to explain less than a third of the cognitive gap, which points to the importance of other mechanisms such as disturbed gut microbiota. The findings underline the need for a precautionary approach in responding to requests for a planned cesarean when there are no apparent elevated risks from vaginal birth.

Malnutrition is the consequence of a combination of inadequate intake of protein, carbohydrates, micronutrients, and frequent infections (Udani, 1992). Malnutrition is associated with both structural and functional pathology of the brain (Upadhyaya et al., 1992). In the present study, the child's intake was recorded for 3 nonconsecutive days, including the vacation, to find out the consumption of the child from major and minor nutrients. Table (2) illustrates the 


\section{Rania A.Bassuoni - Laila Hussein - Magda S.Mohamed Zeinab M.Monir and Ashraf A.AbdEl-Megeid}

mean Total Calorie, Protein, Fat, and Carbohydrate intake by children using data collected by the 24- hour recall and compared to Recommended dietary allowance intake. The mean average total calories recommended for children were $1031.514 \pm 9.94 \mathrm{Kcal}$ and the percentage of the actual total calories that were supposed to take were $114.29 \%$, the total recommended Protein intake was $51.56 \pm 0.49 \mathrm{~g}$ while the percentage of actual protein intake was $76.31 \%$, the total recommended Fat intake was $28.65 \pm 0.28 \mathrm{~g}$ however the percentage of actual fat intake was $138.019 \%$, and the total recommended Carbohydrate intake was $141.83 \pm 1.367 \mathrm{~g}$ whereas the percentage of actual carbohydrate intake was $100.53 \%$. In our study, it's noticed that the decrease in protein intake, in long run, has serious consequences. Kwashiorkor was also less strongly, but nevertheless significantly, related to cognition at age 11 years (Liu et al., 2003).

On another side, it notices that an increase in fat intake which may cause in the long run over weight and obesity which may have effects on cognitive performance. Obesity may affect brain structure, leptin and insulin dysregulation, oxidative stress, cerebrovascular function, blood-brain barrier, and inflammation (Smith et al., 2011). Some also suggest that obesity-related changes in metabolism interact with age to impair brain functions (Bruce-Keller et al., 2009). The high-fat diet increases oxidative stress and inflammatory signaling in the brain (White et al., 2009). In children, intake of 
Egyptian J. of Nutrition Vol. XXXVI No. 2 (2021)

saturated fatty acids impairs both relational and item memory (Baym et al., 2014).

Brain growth and development are critically dependent on several micronutrients. Table (3) present some mineral intake using data collected by the 24- hour recall and compared to Recommended dietary allowance intake. According to US Institute of Medicine recommends the intake of $90 \mu \mathrm{g}$ daily of iodine for children under 4-8 years of age (Trumbo et al., 2001) and WHO $120 \mu \mathrm{g}$ daily of iodine for those aged 6-12 years (WHO, 2007), On the other hand, the EFSA estimates that adequate iodine intake for children between 4 and 10 years of age is $90 \mu \mathrm{g} /$ day (Arrizabalaga et al., 2018). In our study, the mean average intake of iodine was $83.08 \pm 5.47$ and the percentage of the actual intake among children was92.31\%. According to Domellof et al., (2014) iron is recommended to age 5-9 years 6.1 to $10 \mathrm{mg}$ per day, also FAO/WHO, (2002) recommended that iron intake 6.3 to $8.9 \mathrm{mg} /$ day. In this study iron mean intake was $10.45 \pm 0.56 \mathrm{mg}$ and the percentages of the actual intake among children were $117.42 \%$.

Whereas the selenium RDA was $30-40 \mu \mathrm{g} / \mathrm{d}$, the mean average intake from selenium was $49.32 \pm 2.05$ and the percentage of the actual intake among children was $123.3 \%$. However, zinc RDA was 4.8-5.6 mg/d. In our study, the mean average intake of zinc was $4.75 \pm 0.19 \mathrm{mg}$ and the percentage of the actual intake among children was $84.82 \%$. lodine, a dynamic nutrient present in thyroid hormones, the thyroid hormones are important for brain development and proper 


\section{Rania A.Bassuoni - Laila Hussein - Magda S.Mohamed Zeinab M.Monir and Ashraf A.AbdEl-Megeid}

brain function throughout life and iodine is important for the production of these hormones (Abel et al., 2017).

lodine deficiency increases infant mortality and is the leading preventable cause of mental deficiency in childhood (Nyaradi et al., 2013). Iron plays a vital role in brain function and is involved in brain energy production, neurotransmitter synthesis, and myelination. Thus, brain areas responsible for cognitive outcomes are also sensitive to iron deficiencies (Hermoso et al., 2011).

Cross-sectional, longitudinal, and intervention studies show that iron deficiency with or without anemia has adverse effects on cognitive development and performance in children. There is a preponderance of evidence demonstrating that anemic children have poorer cognition and school achievement than non-anemic children (Jáuregui-Lobera, 2014). The biological effects of selenium on brain health are mediated by selenium-containing proteins (selenoproteins), with evidence that this micronutrient is utilized by cells via the presence of selenocysteine (SeCys) amino acid residues in 25 identified selenoproteins. Among the different roles played by selenoproteins, it is noted that at least one-third have antioxidant characteristics, which is essential for neuroprotection (Cardoso et al., 2015).

However, studies regarding the association of Se status and cognitive performance to date have been limited to animal models or 
Egyptian J. of Nutrition Vol. XXXVI No. 2 (2021)

related to age-induced memory loss in humans (Qin et al., 2014). Zinc is a vital modulator of intracellular and intercellular neuronal signaling (Sensi et al., 2011) that is found in high levels in the brain particularly the hippocampus, considered as the area involved in learning and memory (Levenson, 2006), and in the amygdala, striatum and neocortex (Bitanihirwe and Cunningham, 2009).

Zinc is essential for the activity of a large number of metalloenzymes, cellular functions including RNA and DNA synthesis (Terhune and Sandstead, 1972), cellular growth, differentiation, and metabolism. During early development, cellular activity may be particularly sensitive to zinc deficiency, which has been shown to compromise cognitive development (Black, 2003).

Experimental studies in animals have shown that, during the early stages of brain development, deficiency of zinc caused brain defects, reducing the cerebellum size and altering zinc homeostasis, whereas zinc deficiency during the latter stages of brain development impaired function (Takeda, 2001).

Table (4) present some vitamins intake using data collected by the 24-hour recall and compared to Recommended dietary allowance intake. According to (FAO/WHO, 2002) vitamin $A$ recommendation was $450-500 \mathrm{RE} / \mathrm{d}$. in our study vitamin $A$ intake among children was $293.83 \pm 23.24$ R.E and the percentage of the actual intake among children was $58.76 \%$. However, vitamin B1and B2 recommendation was $0.6-0.9 \mathrm{mg} / \mathrm{d}$. the mean average intake of vitamin $B 1$ and $B 2$ were $0.41 \pm 0.04 \mathrm{mg}$ and $0.47 \pm 0.03 \mathrm{mg}$ respectively 


\section{Rania A.Bassuoni - Laila Hussein - Magda S.Mohamed Zeinab M.Monir and Ashraf A.AbdEl-Megeid}

and the percentage of the actual intake among children was 45.56 and $52.22 \%$ respectively.

Whereas Vitamin C recommended was $30-35 \mathrm{mg} / \mathrm{d}$ the mean average intake from vitamin $\mathrm{C}$ was $16.51 \pm 0.97 \mathrm{mg}$ and the percentage of the actual intake among children was $47.17 \%$. Vitamin A plays a vital role as an antioxidant that reduces lipid peroxidation (Carney et al., 1991), the production of ROS, apoptosis, and protein and DNA oxidative damage. Vitamin A deficiency was also linked to iron deficiency anemia, a risk factor for cognitive impairment.

Epidemiological evidence from observational studies thus far suggests that those antioxidants in the diet, supplements, and serum may play a neuroprotective role (Park et al., 2018). Low levels of these $B$ vitamins have been associated with increased homocysteine (Hcy), known to have a direct neurotoxic effect (Ho et al., 2001). Also (Kim et al., 2007) reported that hyperhomocysteinemia may be a significant related risk factor for mild cognitive impairment $(\mathrm{MCl})$. The biological benefits of the water-soluble vitamin C (L-ascorbic acid or ascorbate) are acting as a reducing agent, donating electrons in various enzymatic and non-enzymatic reactions (Hatch, 1995).

Increasing evidence is pointing to vitamin $\mathrm{C}$ as a main redox homeostatic factor in the central nervous system, relating to a poor dietary intake of Vitamin $C$ to adverse effects on cognitive performance (Tveden-Nyborg and Lykkesfeldt, 2009). Several in 
Egyptian J. of Nutrition Vol. XXXVI No. 2 (2021)

vitro and in vivo experiments have supported an essential role for Vitamin $C$ in the brain, both as a powerful antioxidant and scavenger of ROS, as well as a key factor in the recycling of other brain antioxidants (Lykkesfeldt et al., 2007).

The laboratory analysis used in the biochemical tests is shown in table (5). The urine taken from the children in the study was used to assist lodine. The results show that the mean average of urinary iodine was $155.29 \pm 3.53 \mu \mathrm{g} / \mathrm{l}$, whereas the blood taken from children was used to analyze hemoglobin. The results show that the mean average of blood hemoglobin was $11.49 \pm 0.07 \mathrm{~g} / \mathrm{dl}$. Its notice that there is no iodine deficiency or anemia among the children, these results reflect the intake of food, especially iron and iodine. Aref and Khalifa, (2019) reported that the prevalence of anemia was $38.7 \%$ among males were $23.3 \%$, while $53.8 \%$ among females with a statistically significant difference. Elsayed et al., 2015 reported that iodine deficiency (ID) $(<100 \mu \mathrm{g} / \mathrm{L})$ is present among $10 \%$ of the studied primary schoolchildren in seven governorates

The Wechsler IQ tests for children are the most frequently used individual IQ test used worldwide. It's providing two primary index scores: verbal tests which contain six tests Information, Comprehension, Arithmetic, Similarities, Vocabulary and Digit Span, and Performance tests which contain Picture completion, Picture Arrangements, Block design, object assembly, coding, and Maze.

These tests convert to scores that express the IQ of children. IQ results among the children in our study showed in table (6). This 


\section{Rania A.Bassuoni - Laila Hussein - Magda S.Mohamed Zeinab M.Monir and Ashraf A.AbdEl-Megeid}

study showed that the Verbal IQ of children was $98.43 \pm 0.99$, the performance IQ of children was $95.09 \pm 1.14$ and the total IQ was $96.69 \pm 0.42$. The results of IQ tests showed a normal range average in children's IQ (the average ranges were 90-109). From the previous results its childhood, while a healthy diet, associated with high intakes of nutrient rich foods described normal to the children in the study to have good IQ results. Northstone et al., 2012 reported that poor diet associated with high fat, sugar, and processed food content in early childhood may be associated with small reductions in IQ later at about the time of IQ assessment may be associated with small increases in IQ.

\section{Conclusion}

From the previous data, it's found that the nutritional status may affect cognitive development and we suggested that interventions and dietary supplements may improve cognitive abilities in children so Future studies may confirm or deny that.

\section{Acknowledgment}

The authors are grateful to the participants and their mothers, who without their cooperation this study could not be completed.Also thanks to Dr. Mones M. AbuShady, Departments of Child Health National research center, Giza, Egypt for the ANOVA analysis. 
Egyptian J. of Nutrition Vol. XXXVI No. 2 (2021)

\begin{tabular}{c|c|c|c}
\hline Parametes & Boys & Girls & Children \\
\hline Sex (Number) & 25 & 26 & 51 \\
\hline Age (Month) & $98.38 \pm 2.39$ & $93.18 \pm 2.53$ & $95.73 \pm 1.77$ \\
\hline Civilize Residence (\%) & 100 & 100 & 100 \\
\hline Normal (vaginally) Delivery (\%) & 39 & 30.7 & 33.33 \\
\hline Birth weight (kg) & $3.52 \pm 0.09$ & $3.34 \pm 0.08$ & $3.43 \pm 0.06$ \\
\hline Breast Feeding (\%) & 48 & 46.15 & 47.06 \\
\hline Technology Time (hour/d) & $4.16 \pm 0.26$ & $4.58 \pm 0.26$ & $4.37 \pm 0.18$ \\
\hline
\end{tabular}

Table (1): Characteristics of the Study Population (Mean \pm SE). 
Rania A.Bassuoni - Laila Hussein - Magda S.Mohamed Zeinab M.Monir and Ashraf A.AbdEl-Megeid

\begin{tabular}{|c|c|c|c|c|}
\hline Play Sport (\%) & 52 & 50 & 50.98 & ${ }^{*}$ Bo \\
\hline Weight (kg) & $24.64 \pm 0.61$ & $22.69 \pm 0.58$ & $23.65 \pm 0.44$ & dy \\
\hline Height $(\mathrm{cm})$ & $124.6 \pm 1.17$ & $121.1 \pm 1.30$ & $122.8 \pm 0.90$ & \\
\hline BMI'Prgamaters & 15.79E0.184 & $15.45 \pm 0.2$ girls & $15.62 \pm 0.9$ quild & \\
\hline $\begin{array}{l}\text { MUA" }(\mathrm{cm})_{\text {Energy }}(\mathrm{kcal}) \\
\end{array}$ & $\begin{array}{l}1863 \pm 0.33 \\
1182.68+43.45\end{array}$ & $\begin{array}{l}19.14+0.47 \\
1167.64+39\end{array}$ & 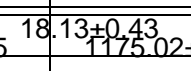 & 29.12 \\
\hline
\end{tabular}

Mass Index

**Mid Upper Arm

Table (2): Total Calories and Macro Nutrient Intake among Children (Mean \pm SE) 
Egyptian J. of Nutrition Vol. XXXVI No. 2 (2021)

\begin{tabular}{|c|c|c|c|}
\hline Protein $(\mathrm{g})$ & $39.85 \pm 1.28$ & $38.55 \pm 1.55$ & $39.19 \pm 0.99$ \\
\hline Fat (g) & $38.81 \pm 1.81$ & $3999 \pm 1.81$ & $39.40 \pm 1.27$ \\
\hline Parameterso* (g) & Boy $\$ 44.84 \pm 5.13$ G & $139.04 \pm 4.79 h i t$ & en $141.88 \pm 3.47$ \\
\hline
\end{tabular}

${ }^{*}$ Carbohydrate

Table (3): Minerals Intake among Children (Mean \pm SE) 
Rania A.Bassuoni - Laila Hussein - Magda S.Mohamed Zeinab M.Monir and Ashraf A.AbdEl-Megeid

\begin{tabular}{c|c|c|c}
\hline lodine $(\mu \mathrm{g})$ & $86.77 \pm 8.33$ & $79.54 \pm 7.23$ & $83.08 \pm 5.47$ \\
\hline Iron $($ mFedrameters & $11.14 \pm 0.86$ oys & $9.79 \pm 0.72$ & Girls $10.45 \pm 0.56$ Children \\
\hline Selenium $(\mu \mathrm{g})$ & $50.18 \pm 3.13$ & $48.49 \pm 2.70$ & $49.32 \pm 2.05$ \\
\hline Zinc $(\mathrm{mg})$ & $4.63 \pm 0.23$ & $4.86 \pm 0.29$ & $4.75 \pm 0.19$ \\
\hline
\end{tabular}

Table (4): Vitamins Intake among Children (Mean \pm SE) 
Egyptian J. of Nutrition Vol. XXXVI No. 2 (2021)

\begin{tabular}{|c|c|c|c|c|c|}
\hline Vitamin A (RE) & $\begin{array}{r}273.6 \\
+29.08 \\
\end{array}$ & & $\begin{array}{r}313.2 \\
\pm 36.15 \\
\end{array}$ & & $\begin{array}{r}293.83 \\
\pm 23.24 \\
\end{array}$ \\
\hline $\begin{array}{l}\text { Parameters } \\
\text { Vitamin B1 (mg) }\end{array}$ & Boys 0.37 & & Girls 0.45 & \multicolumn{2}{|r|}{ Children0.41 } \\
\hline $\begin{array}{c}\text { Urinary lodine }(\mu g / L) \\
\text { Vitamin B2 }\end{array}$ & $\begin{array}{r}5.1 \pm 4.73 \\
0.51 \\
\end{array}$ & 15 & $\begin{array}{r}5.45 \pm 5 . \frac{ \pm}{3} 9.07 \\
0.42 \\
\end{array}$ & 155 & $\begin{array}{r}.29 \pm 3.53 .04 \\
0.47\end{array}$ \\
\hline$(\mathrm{mg})$ & \pm 0.04 & & \pm 0.04 & & \pm 0.03 \\
\hline Vitamin C (mg) & $16.35 \pm 1$. & & $16.67 \pm 1.1$ & & $\begin{array}{l}16.51 \\
\pm 0.97\end{array}$ \\
\hline
\end{tabular}

Table (5): Biochemical Analysis of Children (Mean $\pm S E$ ) 
Rania A.Bassuoni - Laila Hussein - Magda S.Mohamed Zeinab M.Monir and Ashraf A.AbdEl-Megeid

\begin{tabular}{c|c|c|c}
\hline $\begin{array}{c}\text { Blood Hemoglobin } \\
(\mathrm{g} / \mathrm{dl})\end{array}$ & $11.45 \pm 0.08$ & $11.54 \pm 0.12$ & $11.49 \pm 0.07$ \\
\hline
\end{tabular}

Table (6): Intelligence Quotient (I.Q) Scale among Children (Mean \pm SE) 
Egyptian J. of Nutrition Vol. XXXVI No. 2 (2021)

\begin{tabular}{c|c|c|c}
\hline Parameters & Boys & Girls & Children \\
\hline Verbal IQ & $98.08 \pm 1.42$ & $98.77 \pm 1.39$ & $98.43 \pm 0.99$ \\
\hline Performance IQ & $94.48 \pm 1.73$ & $95.69 \pm 1.51$ & $95.09 \pm 1.14$ \\
\hline Total IQ & $96.2 \pm 0.51$ & $97.15 \pm 0.65$ & $96.69 \pm 0.42$ \\
\hline
\end{tabular}

\section{References}

Abdel-Tawab, N.; Oraby, D. and Hassanein, N. (2018). 


\section{Rania A.Bassuoni - Laila Hussein - Magda S.Mohamed Zeinab M.Monir and Ashraf A.AbdEl-Megeid}

Caesarean section deliveries in Egypt: trends, practices, perception and cost. Technical Report.1-51.

Abel, H.M.; Caspersen, I. D.; Meltzer, H.M.; Haugen, M.; Brandlistuen, R.E.; Aase, H.; Alexander, J.; Tprheim, L.E. and Brantsaeter, A. (2017):

Suboptimal Maternal lodine Intake Is Associated with Impaired Child Neurodevelopment at 3 Years of Age in the Norwegian Mother and Child Cohort Study. J Nutr.147 (7):1314-1324.

Allen, L.; de Benoist, B.; Dary, O. and Hurrell, R. (2006):

Guidelines on food fortification with micronutrients. Geneva: World Health Organization/Food and Agriculture Organization.

Aref, M I. and Khalifa, H.O. (2019):

Prevalence of Anemia and associated among school -age children in Al-HARAM zone, Giza governorate, Egypt. ALAzhar Medical Journal. 12, 48 (2): 165-176.

Arrizabalaga, J.J.; Jalón, M.; Espada, M.; Cañas, M.; Arena, J.M. and Vila, L. (2018):

Estado De Nutrición De Yodo Y Prevalencia De ConcentracionesAnormales De TSH En La Población Escolar De 6-7 Años De La ComunidadAutónoma Del País Vasco. Endocrinol. Diabetes Nutr. ;65:245-310

Baym, C. L.; Khan, N. A. and Monti, J. M. (2014): 
Egyptian J. of Nutrition Vol. XXXVI No. 2 (2021)

Dietary lipids are differentially associated with hippocampaldependent relational memory in prepubescent children," American Journal of Clinical Nutrition, 99(5): 10261033.

Best, C.; Neufingerl, N.; Van, Geel L.; Van den Briel, T. and Osendarp, $S$ (2010):

The nutritional status of school-aged children: why should we care? Food Nutr Bull. 31(3):400-417.

Bitanihirwe, B.K.Y. and Cunningham, M.G. (2009):

Zinc the brain's dark horse. Synapse. 63: 1029-1049.

Black, M.M. (2003):

Micronutrient deficiencies and cognitive functioning. $J$ Nutr .133: 3927S-3931S.

Bruce-Keller, A. J.; Keller, J. N. and Morrison, C. D. (2009):

Obesity and vulnerability of the CNS, Biochimica et BiophysicaActa-Molecular Basis of Disease, 1792 (5): 395400.

Bryan, J.; Osendarp, S.; Hughes, D.; Calvaresi, E.; Baghurst, K., and Klinken, J. (2004):

Nutrients for Cognitive Development in School-aged Children. Nutrition Reviews. 62, (8): 295-306. 


\section{Rania A.Bassuoni - Laila Hussein - Magda S.Mohamed Zeinab M.Monir and Ashraf A.AbdEI-Megeid}

Cardoso, B.R.; Roberts, B.R.; Bush, A.I. and Hare, D.J. (2015):

Selenium, selenoproteins and neurodegenerative diseases. Metallomics.7:1213-1228.

Carney, J.M.; Starke-Reed, P.E.; Oliver, C.N.; Landum, R.W.; Cheng, M.S.; Wu, J.F. and Floyd, R.A. (1991):

Reversal of age-related increase in brain protein oxidation, decrease in enzyme activity, and loss in temporal and spatial memory by chronic administration of the spin-trapping compound N-tert-butyl-alpha-phenylnitrone. Proc. Natl. Acad. Sci. USA. 88: 3633-3636.

de Benoist, B.; McLean, E.; Egli, I. and Cogswell, M. (2008):

Worldwide prevalence of anaemia 1993-2005: WHO Global Database on Anemia. Geneva and Atlanta, Ga, USA: World Health Organization and Centers for Disease Control and Prevention.

Domellof, M.; Braegger, C.; Campoy, C. and Colomb, V. (2014):

Iron Requirements of Infants and Toddlers. Journal of Pediatric Gastroenterology and Nutrition 58(1)119-129.

Elsayed, H.H.; Abd El-Rahman, M. K. and Tawwfik, A.A. (2015): 
Egyptian J. of Nutrition Vol. XXXVI No. 2 (2021)

lodine Status of Primary School Children in Different Egyptian Environments. The Egyptian Journal of Hospital Medicine.61: 451- 458.

FAO/ WHO (2002):

Human and vitamin mineral requirements. Rome: FAO. Report a Joint FAO/WHO expert consultation.

Golub, M. S.; Keen, C.L.; Gershwin, M.E. and Hendrickx, A. G. (1995):

Developmental Zinc Deficiency and Behavior. Journal of Nutrition. 125(8):2263S-2271S.

Hatch, G.E (1995):

Asthma, inhaled oxidants, and dietary antioxidants. Am. J. Clin. Nutr.61:625S-630S.

Hermoso, M.; Vucic, V.; Vollhardt, C.; Arsic, A.; Roman-Viñas, B. and Iglesia-Altaba, I. (2011):

A Review, The Effect of Iron on Cognitive Development and Function in Infants, Children and Adolescents: Annals of Nutr and Metab. 154-165.

Ho, P.I.; Collins, S.C.; Dhitavat, S.; Ortiz, D.; Ashline, D.; Rogers, E. and Shea, T.B. (2001):

Homocysteine potentiates beta-amyloid neurotoxicity: role of oxidative stress. J Neurochem. 78:249-253. 


\section{Rania A.Bassuoni - Laila Hussein - Magda S.Mohamed Zeinab M.Monir and Ashraf A.AbdEI-Megeid}

Ismaiel, E. and Kamel, M. (1999):

Wechsler intelligence scale for children revised, Arabic version, 7th edn. El-Nahda El Massryia, Cairo.

Jáuregui-Lobera, I. (2014):

Iron deficiency and cognitive functions. Neuropsychiatr Dis Treat. 10:2087-2095.

Jelliffe, D. P.; Jelliffe, E. F. P.; Zerfas, A. and Neumann, G. G. (1989):

Community nutrition assessment. Oxford university pree. Oxford New York.

Kaufman, Alan S; EngiRaiford, S. and Coalson, Diane L. (2016): Intelligent testing with WISC-V. Hoboken, New Jerset; John Wiley \&Son.p237.ISBN978-1-118-58923-6.

Kim, J.; Park, M.H.; Kim, E.; Han, C.; Jo. S.A. and Jo, I. (2007): Plasma homocysteine is associated with the risk of mild cognitive impairment in an elderly Korean population. $J$ Nutr.137:2093-2097

Kuczmarski, R.J.; Ogden, C.L.; Guo, S.S.; Grummer-Strawn, L.M.; Flegal, K.M. and Mei, Z. (2002): 
Egyptian J. of Nutrition Vol. XXXVI No. 2 (2021)

2000 CDC Growth Charts for the United States: methods and development. Vital Health Stat,11(246):1-190.

Levenson, C.W. (2006):

Regulation of the NMDA receptor: implications for neuropsychological development. Nutr Rev.64: 428-432.

Liu, J.; Raine, A.; Venables, P.; Dalais, C. and Mednick, S. A. (2003):

Malnutrition at Age 3 Years and Lower Cognitive Ability at Age 11 Years. Arch PediatrAdolesc Med. 157(6): 593-600.

Lykkesfeldt, J.; Trueba, G.P.; Poulsen, H.E. and Christen, S. (2007):

Vitamin C deficiency in weanling guinea pigs: Differential expression of oxidative stress and DNA repair in liver and brain. Br. J. Nutr. 98, 1116-1119.

Martorell, R.; Rivera, J.; Kaplowitz, H. and Pollitt, E. (1992):

Long-term consequences of growth retardation during early childhood. In: Hernandez M, Argenta J, eds. Human growth: basic and clinical aspects. Amsterdam: Elsevier Scienc. 1439.

Mazicioglu, M. M.; Hatipoğlu, N.; Oztürk, A. and Kurtoğlu, S. (2010): 


\section{Rania A.Bassuoni - Laila Hussein - Magda S.Mohamed Zeinab M.Monir and Ashraf A.AbdEl-Megeid}

Waist circumference and mid-upper arm circumference in evaluation of obesity in children aged between 6 and 17 years. J Clin Res PediatrEndocrinol .2(4):144-50.

Moussa, W. (1999):

Assessment of Nutritional Status of the individual and the community. 6th Regional training course in Nutrition Institute, Cairo, Egypt.

Northstone, K.; Joinson, C.; Emmett, P.; Ness, A. and Paus, T. (2012):

Are dietary patterns in childhood associated with IQ at 8 years of age? A population-based cohort study. J Epidemiol Community Health.66 (7):624-8.

Nyaradi, A.; Li, J.; Hickling, S.; Foster, J. and Oddy, W. (2013):

The role of nutrition in children's neurocognitive development, from pregnancy through childhood. Front Hum Neurosci 26;7:97.

Park, S.; Kim, H.K.; Myung, W.; Yoo, J.H.; Shin, S.J.; Na, D.L; Kim, S.Y.; Lee, J.-H.; Kim, S.Y. and Han, S.H.(2018):

Risk Factors of Behavioral and Psychological Symptoms in Patients with Alzheimer Disease: The Clinical Research of Dementia of South Korea Study. Korean J. Fam. Med. 40, 16-21. 
Egyptian J. of Nutrition Vol. XXXVI No. 2 (2021)

Polidano, C.; Zhu, A. and Bornstein, J. (2017):

The relation between cesarean birth and child cognitive development. Scientific RePOrTs.7: 11483.

Qin, F.; Yuan, H.; Nie, J.; Cao, Y. and Tong, J.(2014):

Effects of nano-selenium on cognition performance of mice exposed in $1800 \mathrm{MHz}$ radiofrequncy fields. Wei Sheng Yan Jiu.43:16-21.

Sensi, S.L.; Paoletti, P.; Koh, J.Y.; Aizenman, E.; Bush, A.I. and Hershfinkel, M. (2011):

The neurophysiology and pathology of brain zinc. $J$ Neurosci. 31:16076-16085.

Shaklai, N.; Yguerabide, J. and Ranney, H. (1977):

Interaction of hemoglobin with red blood cell membranes as shown by a fluorescent chromophore. Biochemistry.16(25): 5585-5592

Smith, E.; Hay, P.; Campbell, L. and Trollor, J. N. (2011):

A review of the association between obesity and cognitive function across the lifespan: implications for novel approaches to prevention and treatment. Obesity Reviews. 12(9): 740755.

Sommer, A. and Davidson, F.R. (2002): 


\section{Rania A.Bassuoni - Laila Hussein - Magda S.Mohamed Zeinab M.Monir and Ashraf A.AbdEl-Megeid}

Assessment and control of vitamin A deficiency: The Annecy Accords. J Nutr. 132:2845S-50S

Srivastava, A.; Mahmood, S.; Srivastava, P.; Shrotriya, V. and Kumar, B. (2012):

Nutritional status of school-age children - A scenario of urban slums in India. Archives of Public Health, 1-70:8.

Takeda, A. (2001):

Zinc homeostasis and functions of zinc in the brain. Biometals. 14: 343-351.

Terhune, M.W. and Sandstead, H.H. (1972):

Decreased RNA polymerase activity in mammalian zinc deficiency. Science. 177: 68-69.

Trumbo, P.; Yates, A.A.; Schlicker, S. and Poos, M. (2001):

Dietary reference intakes: vitamin $A$, vitamin $K$, arsenic, boron, chromium, copper, iodine, iron, manganese, molybdenum, nickel, silicon, vanadium, and zinc. J. Am. Diet. Assoc.101:294-301.

Tveden-Nyborg, P. and Lykkesfeldt, J. (2009):

Does vitamin $C$ deficiency result in impaired brain development in infants? Redox Rep. 14, 1-6 
Udani, P.M. (1992):

Brain and various facets of child development. Indian $\mathrm{J}$ Pediatr. 59:165-186.

Upadhyaya, S.K.; Saran, A.; Agarwal, D.K.; Singh, M.P. and Agarwal, K.N. (1992):

Growth and behavior development in rural infants in relation to malnutrition and environment. Indian Pediatr. 29:595-606.

Wachs, T.D. (2000):

Nutritional deficits and behavioural development. Int $\mathrm{J}$ Behav Dev.24:435-441.

Whaley, S.; Allen, L.H.; Guthrie, D.; Weiss, R.E. and Demment, M,W. (2003):

Animal source foods improve dietary quality, micronutrient status, growth and cognitive function in Kenyan school children: background, study design and baseline findings. $J$ Nutr; 133:3941S-9S.

White, C. L.; Pistell, P. J. and Purper, M. N. (2009):

Effects of high fat diet on Morris maze performance, oxidative stress, and inflammation in rats: contributions of maternal diet. Neurobiology of Disease. 35(1): 3-13.

World Health Organization (WHO) (2007): 


\section{Rania A.Bassuoni - Laila Hussein - Magda S.Mohamed Zeinab M.Monir and Ashraf A.AbdEl-Megeid}

Assessment of lodine Deficiency Disorders and Monitoring their Elimination: A Guide for Programme Managers. World Health Organization; Geneva, Switzerland:

\section{World Health Organization(WHO) (2013):}

Urinary iodine concentrations for determining iodine status deficiency in populations. Vitamin and Mineral Nutrition Information System. Geneva: World Health Organization. 
Egyptian J. of Nutrition Vol. XXXVI No. 2 (2021)

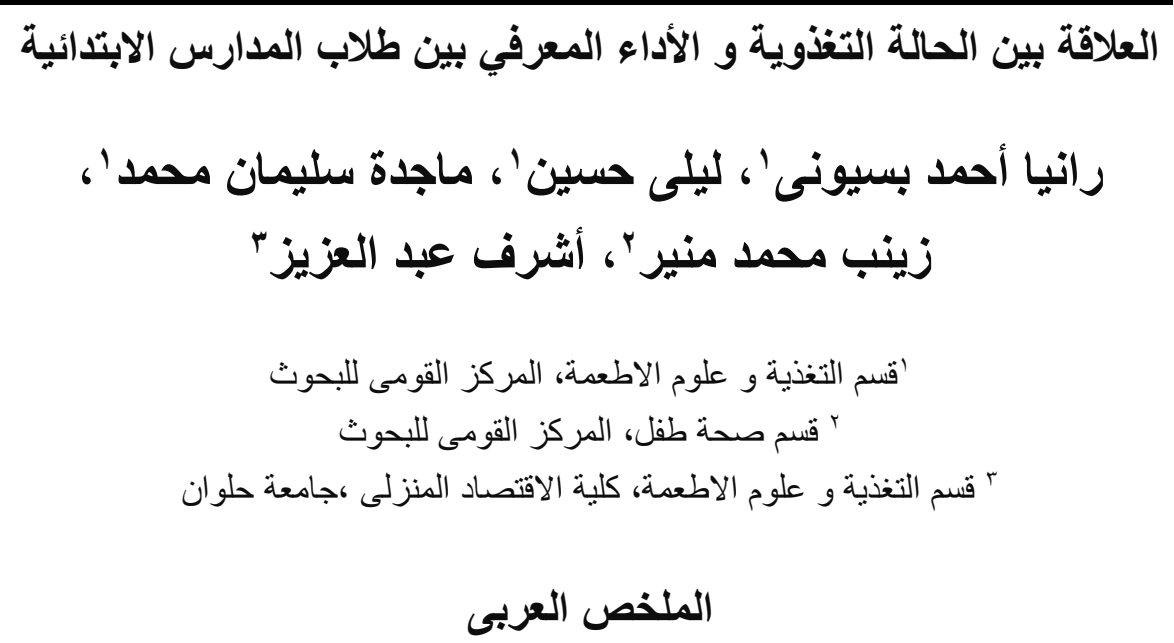

اتباع نظام غذائى سليم ضروري لصحة العقل. التغذية الصحية لها دور هام خاصةً في مراحل

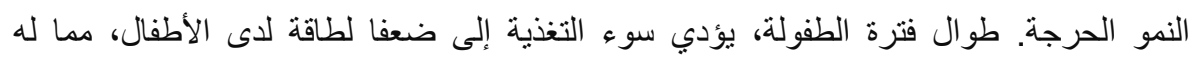

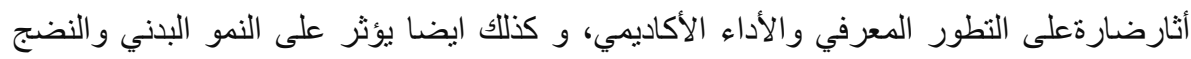

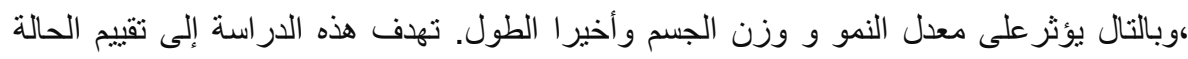

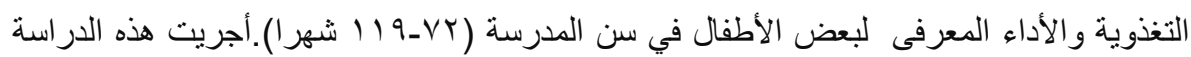

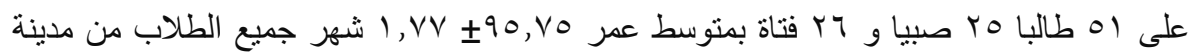

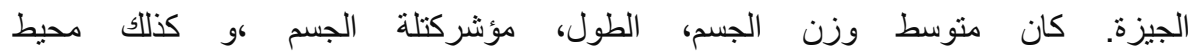

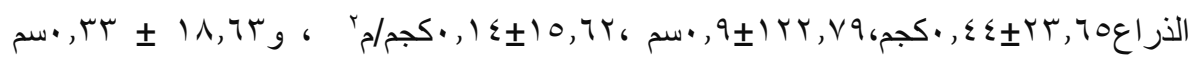

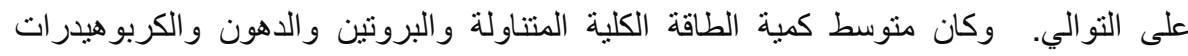

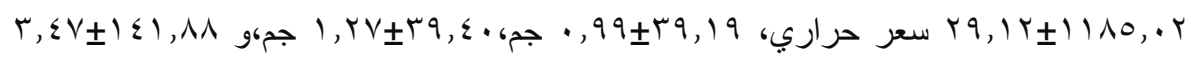

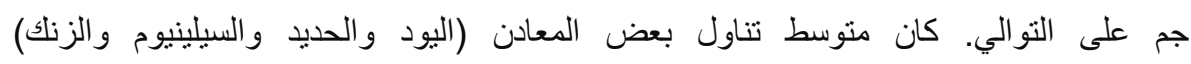
و

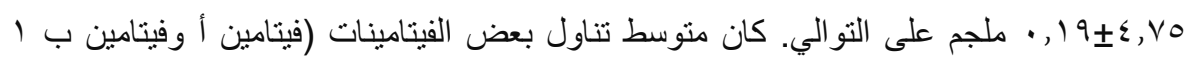

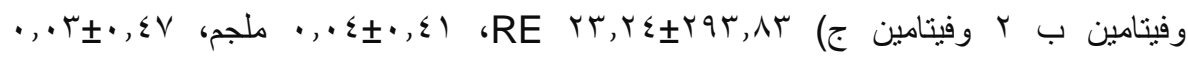

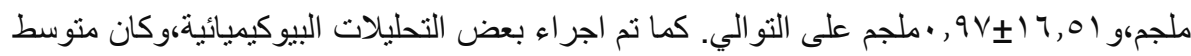

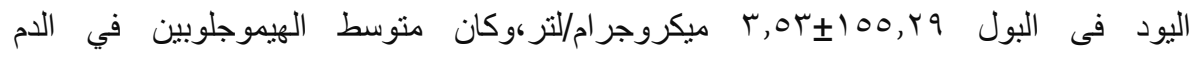




\section{Rania A.Bassuoni - Laila Hussein - Magda S.Mohamed}

\section{Zeinab M.Monir and Ashraf A.AbdEI-Megeid}

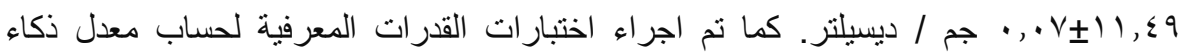

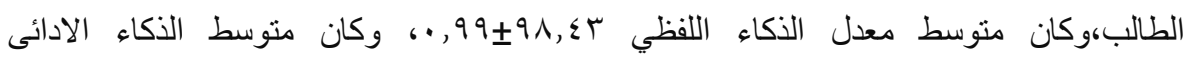

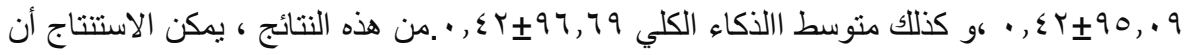

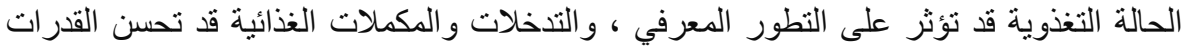

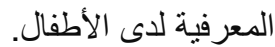

الكلمات الدالة: الحالة التعذوية ، اليود فى البول، القدرات المعرفية ، اختبار ات وسكلر 